\title{
VARIETAL DIFFERENCES IN NIGERIA MAIZE GRAIN
}

\author{
J.A. AREMU ${ }^{1}$, F. OLADOYINBO ${ }^{1}$, L.M. DUROSINMI ${ }^{2}$, E.O. DARE ${ }^{1}$ and A.K. AKINLABI ${ }^{1}$
}

${ }^{1}$ Department of Chemistry, Federal University of Agriculture, Abeokuta

${ }^{2}$ Department of Chemistry, Obafemi Awolowo University, Ile Ife

*Corresponding Author: E-mail: are_ade@yahoo.com

Received 28 July 2020; accepted 14 September 2020, published online 10 October 2020

\begin{abstract}
Eight different improved varieties of maize grain from IITA, Ibadan, Oyo state, Nigeria and a local maize from Bodija market, Ibadan were examined for their varietal differences. Proximate analysis of the improved varieties of the maize grain and the local maize were carried out. Elemental analysis of the improved varieties of the maize and the local maize were also carried out by using spectrophotometry method. The moisture content of the improved varieties of the maize ranged from 7.75-10.05\% and the local maize was $9.25 \%$. The ash content of the improved varieties maize varied from $1.45 \%-3.47 \%$ while the local maize gave $2.22 \%$. The protein, oil, crude fibre and carbohydrate contents of the improved maize varieties ranged from $9.35-11.15 \%, 3.50 \%-8.42 \%$, $1.40 \%-3.55 \%$ and $65.35 \%-73.82 \%$ respectively. Similarly, the local maize variety gave $9.40 \%, 4.25 \%, 1.55 \%$ and $73.55 \%$ for the protein, oil, crude fibre and carbohydrate contents respectively. The improved maize varieties gave higher results for protein, crude fiber and oil contents than the local maize variety. The elemental analysis showed that the sodium element in the improved varieties of the maize was found between 85.01-165.11 $\mathrm{mg} / 100 \mathrm{~g}$ while the local maize was $110.21 \mathrm{mg} / 100 \mathrm{~g}$. The magnesium, potassium, calcium, manganese, iron, copper and zinc in the improved varieties of the maize were in the range of $27.51-35.54 \mathrm{mg} / 100 \mathrm{~g}, 250,05-307.56$ $\mathrm{mg} / 100 \mathrm{~g}, 1.49-1.64 \mathrm{mg} / 100 \mathrm{~g}, 0.51-1.38 \mathrm{mg} / 100 \mathrm{~g}, 2.52-7.59 \mathrm{mg} / 100 \mathrm{~g}, 1.49-2.75 \mathrm{mg} / 100 \mathrm{~g}$ and $4.25-11.03$ $\mathrm{mg} / 100 \mathrm{~g}$ respectively except the ACR-85TZSR-Y-1 of the improved variety in which manganese was not detected while the mineral elements in the local maize were obtained as $110.21,35.01,247.52,1.47,0.63,4.52$, 2.75, 7.04 respectively. Most of the improved varieties showed higher values of the mineral elements than the local variety except sodium, manganese and copper where lower values were observed..
\end{abstract}

Keywords: Maize, grain, proximate, mineral analysis.

\section{INTRODUCTION}

Food is basic to maintaining desirable nutritional status and in preventing malnutrition. The nutritional status and health of individuals are affected by the food they eat as its quantity and quality are important. Cereals provide food resource for man. In Africa, sorghum and maize are the popular cereals consumed [1]. Inadequacy of agricultural production has reached worrying proportion in many developing countries, especially in subSahara Africa and south Asia, where fall in agricultural production has been exacerbated by natural disaster. Improvement in agricultural yields is responsible for increase in food production. Maize are processed into different food products such as porridges, gruels and pastes [2]. Green maize serves as an important crop in bridging the gap after the long period of dried season, when it is eating, boiled or roasted. The crop provides intake of iron and zinc in the diet of the rural people in Africa because of its consumption [3]. Iron deficiencies during childhood and adolescence can retard mental development, learning capacity and impair physical growth, whereas in adults it reduces the capacity to do physical labour [4]. However, little is known about the genetic variation of micronutrients. Large variation in iron and zinc concentrations in maize have been observed [5]. Concentrations of elements in grains are affected by environmental interaction [6]. Thus selecting varieties with stable expressions of micronutrient concentrations across diverse environment is an aspect of increasing micronutrient concentrations in maize grains.

New cultivars which are species that do not occur naturally, but specially breed tend to double the harvest obtained with traditional variety provided 
they receive necessary amount of water and fertilizer [7]. As a result of wild use of the cultivars and the so called "green revolution", grain production rose sharply in a number of countries and made it possible to achieve higher yields. Improved varieties are those with free pollination, or hybrid product of a formal process of genetic improvement, while local varieties are those obtained from local maize varieties that are originally adopted, from witch farmers make their own selection [8]. New varieties of grains have been adopted in areas where they are technically and economically superior to local varieties. The few publications related to this study have not shown comparison in chemical composition of improved and local varieties and this has brought about the interest in the study. The work reports the difference in improved and local varieties in Nigeria maize grain by carrying out proximate analysis together with mineral contents.

\section{Materials and Methods Sampling}

Improved maize grains were purchased from International Institute of Tropical Agriculture (IITA), Ibadan, Oyo State, Nigeria while the local variety was purchased from Bodija market in Ibadan.

\section{Proximate Analysis}

Moisture content of each sample was determined by drying in Sanyo Gallenkamp Plc M-series oven [9] $5 \mathrm{~g}$ each of the improved maize varieties and the local maize were extracted in a sohxlet extractor with petroleum ether $\left(40-60{ }^{0} \mathrm{C}\right)$ in order to determine crude fat according to the method of Maltilda et al. (1992) [1]. $5 \mathrm{~g}$ each of defatted improved maize varieties and the local maize in a pre-treated crucible was dried at $105{ }^{\circ} \mathrm{C}$ and later ashed at $600{ }^{\circ} \mathrm{C}$ for 7 hours in a Sanyo gallenkamp plc muffle furnace [9]. Improved maize varieties and the local maize of $5 \mathrm{~g}$ each was digested at 370 ${ }^{\circ} \mathrm{C}$ till the solution turned green and later turned colourless for crude protein determination [1]. The crude fiber of the improved maize varieties and the local maize was determined through the trichloroacetic acid method according to the method of Lale and Igweburke (2002) [10]. Carbohydrate content was also determined by subtracting the sum of the fat, moisture, crude fibre, ash and protein contents.

\section{Elemental Determination}

In the determination of minerals, the samples were digested in $\mathrm{HNO}_{3} / \mathrm{HClO}_{4}(9 / 1)$ as described by Julshamn et al. (1982) [11]. $\mathrm{Mg}, \mathrm{Ca}, \mathrm{Mn}, \mathrm{Fe}, \mathrm{Cu}$ and $\mathrm{Zn}$ were determined by using Pye Unican Atomic Absorption Spectrophotometer [1], while Na and K were determined by using Flame Photometer [9].

\section{Results and Discussion}

The proximate composition is as presented in Table 1 for the eight different improved varieties and one local maize grain in which the analyses were in duplicate and $5 \%$ deviation was accepted [1].

The moisture contents of the improved varieties ranged between 7.75-10.05\% while that of the local was $9.025 \%$. This agrees with the value of $10.20 \%$ of the local variety and $9.60 \%$ of similar cereals reported by Adeyeye and Ajewole (1992) [7]. The ash content ranged from 1.45-3.47 \% for the improved varieties while the local variety was 2.22 $\%$. These values agree with similar grains reported by Adeyeye and Ajewole (1992) [7]. The oil content of the improved varieties ranged between 3.50-8.42 $\%$ differing from $3.60-3.80 \%$ reported on sorghum by matilda et al (1992) [1] and 2.70-5.50\% reported on cereals by Adeyeye and Ajewale (1992) [7]. The highest oil content was observed in 8321-18 hybrid $(8.42 \%)$ and the least in 8338- 1 hybrid variety $(3.50 \%)$. The crude fibre content of the samples ranged between 1.40-3.52\%. These values agreed with the crude fibre content in a similar study earlier reported on pleurptous tuber-regium by Fasidi and Ekuere (1993) [9] with values ranging from1.30$2.60 \%$. The protein content ranged between 9.35$11.00 \%$ which compared well with $10.00 \%$ reported on sorghum [1]. The total carbohydrate content of the samples ranged from 65.35-75.82\%. The values agreed fairly with $74.10 \%$ reported on cereals by Adeyeye and Ajewole (1992) [7].

The elemental content is shown in Table 2. Potassium was the most abundant mineral element in the studied maize varieties ranging between $247.52 \mathrm{mg} / 100 \mathrm{~g}$ in the local to $307.56 \mathrm{mg} / 100 \mathrm{~g}$ in the improved Western yellow maize varieties (Table2). This result is similar to the earlier report on corn-flour by Fatoki and Bamiro (1990) [13]. 
The preponderance of potassium in the maize varieties may be due to the nutrient within them [9]. The 8321-18 hybrid was the richest with regards to sodium content $(165.11 \mathrm{mg} / 100 \mathrm{~g})$ whereas $8321-18$ and 8338-1 hybrid varieties were in magnesium. In contrast, contents of calcium, iron, copper and zinc were low while manganese was not detected in the ACR-85TZSR-Y-1 hybrid variety (table2) Zinc varied from $4.25 \mathrm{mg} / 100 \mathrm{~g}$ in 8338-1 maize hybrid to $11.03 \mathrm{mg} / 100 \mathrm{~g}$ in $8321-18$ maize variety. The Iron content ranged between $2.52 \mathrm{mg} / 100 \mathrm{~g}-7.59$ $\mathrm{mg} / 100 \mathrm{~g}$ in improve maize Mokwa 87TZPB-SR and open-pollinated Western ACR85TZSR-Y-1 hybrid maize varieties respectively. Copper in two of the improved and local varieties was $2.7 \mathrm{mg} / 100$ $\mathrm{g}$ while $1.49 \mathrm{mg} / 100 \mathrm{~g}-1.58 \mathrm{mg} / 100 \mathrm{~g}$ was obtained for the remaining improved varieties and the local gave $1.47 \mathrm{mg} / 100 \mathrm{~g}$. The analysis revealed low manganese content in all the varieties and was not detected in one of the samples (Table 2). Manganese content therefore varied from below detection limit in the open-pollinated ACR85TZSR-Y-1 to 1.38 $\mathrm{mg} / 100 \mathrm{~g}$ in the 8644-31 hybrid variety.

Table 1: Proximate composition of improved varieties of maize and local maize

\begin{tabular}{lllllll}
\hline Varieties & Moisture $(\%)$ & Ash $(\%)$ & Oil $(\%)$ & Protein $(\%)$ & CrudeFibre $(\%)$ & Cabohydrate $(\%)$ \\
\hline ACR-85TZSR-Y-1 & $9.60 \pm 0.02$ & $1.45 \pm 0.03$ & $4.75 \pm 0.01$ & $9.80 \pm 0.02$ & $1.42 \pm 0.02$ & $72.97 \pm 0.01$ \\
ACR-85TZ SR-W-1 & $8.92 \pm 0.04$ & $3.05 \pm 0.01$ & $8.30 \pm 0.03$ & $10.90 \pm 0.04$ & $2.96 \pm 0.10$ & $65.86 \pm 0.10$ \\
Mokwa- & $9.50 \pm 0.02$ & $2.75 \pm 0.01$ & $8.20 \pm 0.02$ & $10.85 \pm 0.05$ & $2.88 \pm 0.03$ & $65.82 \pm 0.01$ \\
87TZPB-SR & & & & & & \\
Western Yellow & $9.10 \pm 0.03$ & $3.47 \pm 0.02$ & $4.85 \pm 0.02$ & $10.90 \pm 0.01$ & $3.55 \pm 0.01$ & $68.12 \pm 0.02$ \\
$8644-31$ & $7.75 \pm 0.03$ & $3.45 \pm 0.01$ & $8.35 \pm 0.02$ & $11.15 \pm 0.02$ & $3.52 \pm 0.03$ & $65.77 \pm 0.03$ \\
$8321-18$ & $10.0 \pm 0.04$ & $2.72 \pm 0.01$ & $8.42 \pm 0.03$ & $10.35 \pm 0.01$ & $3.10 \pm 0.02$ & $65.35 \pm 0.01$ \\
$8522-2$ & $9.55 \pm 0.02$ & $1.45 \pm 0.01$ & $4.62 \pm 0.03$ & $9.35 \pm 0.03$ & $1.45 \pm 0.03$ & $73.57 \pm 0.01$ \\
$8338-1$ & $9.90 \pm 0.01$ & $1.57 \pm 0.02$ & $3.50 \pm 0.02$ & $9.80 \pm 0.01$ & $1.40 \pm 0.01$ & $73.82 \pm 0.03$ \\
Local & $9.02 \pm 0.04$ & $2.22 \pm 0.03$ & $4.25 \pm 0.03$ & $9.40 \pm 0.02$ & $1.55 \pm 0.04$ & $73.55 \pm 0.03$ \\
\hline
\end{tabular}

Table 2: Mineral composition of improved varieties of maize and local maize

\begin{tabular}{lllllllll}
\hline Varieties & $\mathrm{Na}(\mathrm{mg} / 100 \mathrm{~g})$ & $\mathrm{Mg}(\mathrm{mg} / 100 \mathrm{~g})$ & $\mathrm{K}(\mathrm{mg} / 100 \mathrm{~g})$ & $\mathrm{Ca}(\mathrm{mg} / 100 \mathrm{~g}$ & $\mathrm{Mn}(\mathrm{mg} / 100 \mathrm{~g})$ & $\mathrm{Fe}(\mathrm{mg} / 100 \mathrm{~g})$ & $\mathrm{Cu}(\mathrm{mg} / 100)$ & $\mathrm{Zn}(\mathrm{mg} / 100 \mathrm{~g}$ \\
\hline ACR-85TZSR-Y-1 & $85.01 \pm 0.10$ & $27.51 \pm 0.20$ & $250.05 \pm 0.10$ & $1.52 \pm 0.10$ & Not detected & $7.59 \pm 0.20$ & $1.53 \pm 0.10$ & $5.02 \pm 0.10$ \\
ACR-85TZ SR-W-1 & $110.00 \pm 0.20$ & $35.00 \pm 0.10$ & $250.08 \pm 0.10$ & $1.52 \pm 0.10$ & $0.56 \pm 0.20$ & $7.04 \pm 0.10$ & $1.58 \pm 0.10$ & $6.75 \pm 0.20$ \\
Mokwa-87TZPB-SR & $150.02 \pm 0.04$ & $34.08 \pm 0.03$ & $257.52 \pm 0.04$ & $1.61 \pm 0.04$ & $0.88 \pm 0.04$ & $2.52 \pm 0.10$ & $2.75 \pm 0.10$ & $5.04 \pm 0.03$ \\
Western Yellow & $100.00 \pm 0.02$ & $34.06 \pm 0.20$ & $307.56 \pm 0.10$ & $1.54 \pm 0.10$ & $0.63 \pm 0.04$ & $3.03 \pm 0.20$ & $1.49 \pm 0.20$ & $5.01 \pm 0.10$ \\
$8644-31$ & $100.0 .04 \pm 0.03$ & $34.12 \pm 0.10$ & $255.01 \pm 0.20$ & $1.58 \pm 0.03$ & $1.38 \pm 0.10$ & $3.02 \pm 0.04$ & $2.75 \pm 0.10$ & $8.75 \pm 0.10$ \\
$8321-18$ & $165.11 \pm 0.04$ & $35.54 \pm 0.04$ & $300.02 \pm 0.20$ & $1.64 \pm 0.10$ & $0.55 \pm 0.10$ & $3.55 \pm 0.10$ & $1.53 \pm 0.04$ & $11.03 \pm 0.10$ \\
& & & & & & & & \\
$8522-2$ & $125.16 \pm 0.02$ & $33.08 \pm 0.02$ & $262.59 \pm 0.10$ & $1.56 \pm 0.03$ & $0.58 \pm 0.04$ & $6.06 \pm 0.04$ & $1.57 \pm 0.10$ & $4.52 \pm 0.10$ \\
$8338-1$ & $120.24 \pm 0.04$ & $35.56 \pm 0.03$ & $292.05 \pm 0.04$ & $1.49 \pm 0.03$ & $0.51 \pm 0.10$ & $7.57 \pm 0.10$ & $1.51 \pm 0.10$ & $4.25 \pm 0.10$ \\
Local & $110.21 \pm 0.04$ & $35.01 \pm 0.04$ & $247.52 \pm 0.04$ & $1.47 \pm 0.20$ & $0.63 \pm 0.10$ & $4.52 \pm 0.10$ & $2.75 \pm 0.10$ & $7.04 \pm 0.02$ \\
\hline
\end{tabular}

\section{Discussion}

The highest moisture content was in the 8321-18 hybrid $(10.05 \%)$ and the least in the 8644-31 hybrid maize $(7.75 \%)$. Variation in the moisture content that has no significant effect on the nutritional value of maize grain could be attributed to genetic and environmental factors [2]. Highest value of ash content was observed in the improved open pollinated Western Yellow variety $(3.47 \%)$ and the least in both the improved-pollinated ACR85TZSR-
Y-1 variety (1.45\%) and 8522-hybrid variety (1.45 $\%)$. The ash contents were stable in all the samples except for three varieties with reductions as indicated in Table 1. The oil content of the improved variety was higher than that of the local variety except for the 8338- 1 hybrid variety with a notable reduction. This might be due to general variations, even within the same improved varieties. The higher oil contents in the improved varieties suggest higher nutritional value of oil content, their 
essential fatty acid content and the fat-soluble vitamins contained [1]. Efforts of improving maize varieties tend to enhance major fatty acid in the oil content which prevent deficiency symptoms such as retard growth, increased skin permeability and malfunctions in many organs [2]. It is therefore advantageous to feed infants with improved varieties. It must be noted that if the essential fatty acids in the cereals are protected from oxidation which occurs during handling and processing, they can provide the requirements for individuals in the third world, where large amount of cereals are consumed. Nutritional quality of the improved varieties of fatty acid may prevent disorders in the central nervous system and docosahexanoic acid which is important in brain function [12]. This might be due to leaching of minerals resulting to hybridization of the improved maize variety [1-2]. The highest crude fibre content was obtained in the 8644-31 hybrid variety $(3.52 \%)$ while the least was obtained in the 8338-1 (1.40\%). The high crude fibre observed among the improved varieties might be due to the abundance of nutrient in them [7]. The highest crude protein was obtained in the 8644-31 hybrid variety $(11.15 \%)$ while the $8522-$ hybrid has the least crude protein content $(9.35 \%)$. The improved maize varieties may serve as supplement in rural and urban areas where fish and proteins are expensive [9]. The improved maize varieties are higher in protein values than the local variety. The hybrid maize variety $8338-1$ produced the highest total carbohydrate content $(73.82 \%)$ and the least (65.35\%) was obtained in the 8321-18 maize hybrid. The maize varieties studied were good sources of carbohydrate. The improved varieties may not be ideal for diabetics and those with heart or weight problems due to high carbohydrate content [9].

Locations and varieties of the samples could lead to variations of mineral elements in addition to their genetic contribution [2]. These findings will be beneficial to infants at meeting their nutrient requirement and at improving human nutrition. There will also be some agronomic advantages such as viable and vigorous seedlings, higher resistance to diseases and better land use [13]. Intrinsic elements of food crops represent a pool from which elements can be made available and result in an inexpensive and sustainable contribution of bio available mineral element [14].

\section{Conclusion}

The improved maize varieties were higher in protein content than the local variety. This is an advantage for improvement on low level of protein observed for cereals. However, users may be opportuned to select the varieties desired based on their proximate nutritional qualities.

The improved varieties were higher in moisture, ash, oil and crude fibre contents than the local variety. High crude fibre content tends to be of empirical importance in food digestibility, good bowel activity and favourable blood cholesterol response.

The higher elemental contents of some of the improved varieties compared with the local variety could be attributed to location, fertilizer application and or genetic factors. Potassium, sodium, magnesium, iron, copper and zinc levels showed variations in their accumulations among the improved varieties and between the improved and the local variety.

\section{Refrences}

[1] Matilda Asiedu, Rumen Nilsen, Oyvind lie and Einar lied, 1992. Effect of processing (sprouting and /or fermentation) on sorghum and maize. Proximate, composition, mineral and fatty acids. Food Chemistry,46,351-353.

[2] Sylvester O. O., Abeb M., Bussie M., Ross W. and Raymond P. G., 2003. Assesssment of concentration of Iron and Zinc and bioavaliable Iron in Grains of early maturing tropical maize varieties. Journal of Agricultural and Food Chemistry, 51, 3688-3694.

[3] Ruel, M. T., Bous, H. E., 1998. Plant breeding: a long term strategy for the control of Zinc deficiency in vulnerable population. Am J. Clin.Nutr $<68,488$ 494.

[4] Bouis, E, H., 2002. Plant breeding: A new tool for fighting micronutrient malnutrition. Journal of Nutrition. 132, 4913 -4945.

[5] Oikeh, S.O. ,Kling, I.G., Okoruwa, A.E., 1998. Nitrogen fertilizer management effects on maize grain quality in the West African moist Savanna. Crop Sci., 1056-1061. 
[6] Gregorio, G, H., 2002. Progress in breeding for trace minerals in staple crops. Journal of Nutrition, 132,500-502.

[7] Adeyeye, A. and Ajewole, K., 1992. Chemical composition and fatty acid profile of cereals in Nigeria. Journal of Food Chemistry, 44, 41 - 44.

[8] Luis, A. G. P., Conception, S., Seraf, M. H., 2002. Causual attribute analysis for the use of local and improved maize seed. Publicado Como Articulo en Agrociencin,36,377-387.

[9] Fasidi I. O., and Ekuere U. U., 1993. Studies on pleurptous tuber- regium(fries) singer: cultivation, proximate composition and mineral contemts of seleroita. Food Chemistry, 48,225-258

[10] Lale, N. E. S. and Igweburke, J. U.. 2002. Field infestation of faidherbia (Acacia) albida (Del) A. Chew. Pods by stored product coleopteran in the Nigerian savanna and effect of infestation on nutrient quality. Journal of arid environments. 51, $103-112$.

[11] Julshamn K., Ringdal,o.,Slining, K.E and Breekkan, O.R., 1982. Optimization of the determination of selenium in marine samples in marine samples by atomic absorption spectrometry: comparison of a flameless graphic furnace atomic absorption system. Spectrochem.Acta., 7B,473-782

[12] Weber, P.C., 1989. Are we what we eat? Fatty acid in nutrition and in cell membrane cell functions and disorder induced by dietary conditions in fish, fats, and health, ed. Jonasson, J.E. Svancy Foundation Report no. 4, 9-18.

[13] Fatoki, S. O. and Bamiro, F. O., 1990. Level of $\mathrm{Na}, \mathrm{K}, \mathrm{Ca}$ and $\mathrm{Mg}$ in infant formulae and in cornflour infant feeds. Journal of Food Chemistry, 37, 269-273.

[14] Benezinger, $M$ and Long, J., 2000. The potential for increasing the iron and Zinc density of maize through plant Breeding. Food Nutrition. Bull.21, 397-400 